\title{
Human Papillomavirus Genotype-Specific Persistence and Potential Risk Factors among Korean Women: Results from a 2-Year Follow-up Study
}

\author{
Cecile Ingabire, $\mathrm{MS}^{1}$ \\ Min Kyung Lim, PhD ${ }^{1,2}$ \\ Young-Joo Won, $\mathrm{PhD}^{1,3}$ \\ Jin-Kyoung Oh, $\mathrm{PhD}{ }^{1,2}$
}

${ }^{1}$ Department of Cancer Control and Population Health, National Cancer Center Graduate School of Cancer Science and Policy, Goyang, ${ }^{2}$ Cancer Risk Appraisal and Prevention Branch, Division of Cancer Prevention, National Cancer Center, Goyang, ${ }^{3}$ Cancer Registration and Statistics Branch, Division of Cancer Registration and Surveillance, National Cancer Center, Goyang, Korea

Correspondence: Young-Joo Won, $\mathrm{PhD}$ Department of Cancer Control and Population Health, National Cancer Center Graduate School of Cancer Science and Policy, and Division of Cancer Registration \& Surveillance, National Cancer Control Institute, National Cancer Center, 323 Ilsan-ro, Ilsandong-gu, Goyang 10408, Korea

Tel: 82-31-920-2015

Fax: 82-31-920-2179

E-mail: astra67@ncc.re.kr

Co-correspondence: Min Kyung Lim, PhD Department of Cancer Control and Population Health, National Cancer Center Graduate School of Cancer Science and Policy, and Division of Cancer Prevention, National Cancer Control Institute, National Cancer Center, 323 Ilsan-ro, Ilsandong-gu, Goyang 10408, Korea

Tel: 82-31-920-2016

Fax: 82-31-920-2929

E-mail: mickey@ncc.re.kr

Received July 17, 2017

Accepted August 8, 2017

Published Online August 17, 2017

\section{Purpose}

High-risk human papillomavirus (HPV) infection progression should be considered a critical factor for preventing cervical cancer, although most infections are transient and rarely persist. This study aimed to examine the specific types of HPV infections, their change patterns, and the potential risk factors among Korean women.

\section{Materials and Methods}

We included 4,588 women who visited hospitals in Busan and Suwon for cervical cancer screening, and 1,224 of these women attended a 2-year follow-up. Infection status was evaluated using HPV DNA testing (Hybrid Capture 2) and genotyping testing (Linear Array). Data regarding the potential risk factors for HPV infection were collected by trained nurses using structured questionnaires.

\section{Results}

Among the 1,224 women (mean age, 47 years), 105 women (8.6\%) were HPV-positive at baseline. HPV infections had been cleared among 92 women (87.6\%) within 2 years. Only 13 infections (12.4\%) were remained, and the 10 cases of them are high-risk HPV types including genotype 33, 45, 16, 35, and 52. Among women who were negative at baseline, the HPV incidence was $4.8 \%$. The HPV incidence was marginally associated with having multiple sexual partners (odds ratio, 2.0; 95\% confidence interval, 1.0 to 3.9), although it was not significantly associated with HPV persistence.

\section{Conclusion}

Most HPV infections (88\%) among Korean women were cleared within 2 years, with only a small number of persistent infections. The persistent HPV genotypes were different in our study, compared to those from previous studies. Having multiple sexual partners was associated with acquiring a HPV infection, but not with persistence.

\section{Key words}

Human papillomavirus, Genotype, Persistence, Clearance, Incidence 


\section{Introduction}

Human papillomavirus (HPV) infection can cause cervical cancer, and the cancer burden attributed to this infection varies according to geographical region and the genotype of people who are infected with HPV. It is most prevalent in Africa, Asia, and some European countries, compared to other regions of the world. Thirteen high-risk HPV (HRHPV) types, which are carcinogenic or presumed to be carcinogenic in humans, are frequently detected in patients who develop cervical cancer. For example, HPV types 16 and 18 account for approximately $70 \%$ of all cervical cancer cases [1]. Several epidemiological studies have evaluated the genotype-specific prevalences of HPV, factors that influence HPV acquisition, and the risk of cervical cancer development according to HPV infection status [1-4]. Furthermore, there are various factors that influence cervical cancer development, including viral infection and host factors. Thus, the prevention of cervical cancer relies on our understanding of the progression of HR-HPV infections, which involves persistence, clearance, new infections, and other determinant factors. However, most HPV infections are transient and rarely persist $[5,6]$. Only a few studies in specific countries and populations have considered the HPV genotype-specific incidence, persistence, clearance, and new infections [7-17]. Furthermore, only a few studies have evaluated the natural history of HPV infections in Asian countries, where the prevalence of HPV is high. Moreover, the association with cervical cancer development has been highlighted as a major health issue among women. In Korea, the prevalence of HPV is approximately $20 \%$ among women with normal cytology, based on the Papanicolaou test (Pap test) [18]. In addition, cervical cancer is a leading cancer among Korean women, with an age-standardized incidence of 9.5/100,000 women in 2012 [19]. Despite these data, there is a lack of Korean studies regarding changes in HPV infection status and the factors that contribute to these changes. Therefore, the present study aimed to examine HPV type-specific infections, their change patterns, and the factors that were involved in these changes, based on two HPV tests that were performed 2 years apart for Korean women who visited two centers.

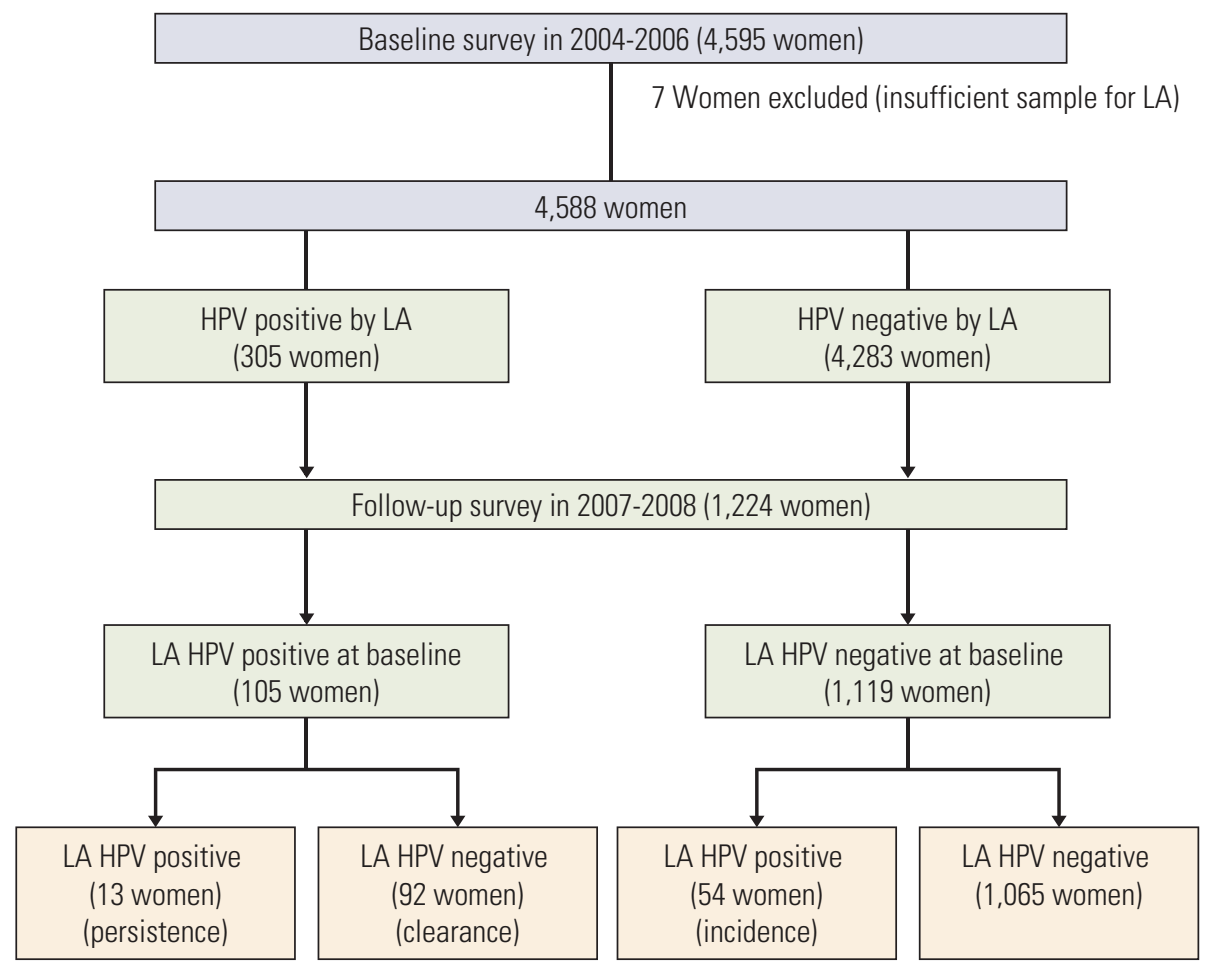

Fig. 1. Participants in baseline and follow-up survey and their classification by the status of human papillomavirus (HPV) infection. LA, linear array. 


\section{Materials and Methods}

\section{Study population}

This retrospective study evaluated prospectively collected data from a baseline test and a test at the 2-year follow-up. A total of 4,595 women visited government-affiliated hospitals in Busan and Suwon (Korea) for baseline testing between November 2004 and December 2006, as part of the National Cervical Cancer Screening Program. Among these women, 1,224 women subsequently attended the follow-up testing during 2007 and 2008. The details of the baseline testing have been described elsewhere [5], and Fig. 1 shows the inclusion and exclusion criteria for the present study.

\section{Data collection}

Data regarding the potential risk factors for HPV infection were obtained using questionnaires at the baseline test. A trained research nurse interviewed each participant and completed the structured questionnaire regarding their socio-demographic characteristics (age, marital status, educational level, and age at marriage), lifestyle behaviors (smoking, alcohol drinking, and number of sexual partners), obstetrical and reproductive history (parity, age of women at first childbirth, oral contraceptive use, intrauterine device use, and hormone therapy), and clinical characteristics (sexually transmitted disease histories for the participant and their partner, family and individual cancer history, and cervical screening history).

The outcome variable was based on the results from two HPV tests at the baseline and follow-up testing. The results were categorized according to the HPV infection change status: (1) type-specific persistence (positivity for the same HPV DNA type in both tests), (2) type-specific HPV clearance (a negative result for a specific HPV type after a previously positive result), and (3) incident HPV infection (a change from HPV DNA negativity at baseline to HPV DNA positivity at the follow-up test). The HPV testing was performed using the Hybrid Capture 2 system (HC2; Digene, Gaithersburg, MA), and HPV genotyping was performed on HC2positive samples using a Linear Array assay (LA; Roche Molecular Systems, Branchburg, NJ) [20].

\section{Statistical analysis}

The proportions of HPV type-specific persistence and clearance were calculated among the 105 women who were HPV-positive, based on their baseline LA results. The incidences of new HPV type-specific infections were calculated among the 1,119 women who were HPV-negative, based on their baseline LA results. Pearson's chi-square test and Fischer exact test was used to assess the frequency distributions of potential risk factors for changing HPV infection status. Logistic regression analyses were also used to evaluate the role of potential risk factors in the changes in HPV infection status. Associations were reported as odds ratios (ORs) and 95\% confidence intervals (CIs). All tests were two-sided, and a p-value of $<0.05$ was considered statistically significant. All analyses were performed using STATA software ver. 13 (StataCorp LP, College Station, TX).

\section{Ethical statement}

The study protocol was approved by the Institutional Review Board of the National Cancer Center, and all participants provided written informed consent at the baseline test.

\section{Results}

Among the 4,588 women who participated in the baseline survey, only 1,224 women were followed-up and included in the present analysis. When we compared the participants from the baseline and follow-up testing, we did not observe any noticeably differences in their socio-demographic, behavioral, and reproductive characteristics, or in their HPV infection rates (S1 Table). The mean patient age at baseline was 47 years (range, 21 to 66 years), most participants were married or cohabitating, $17 \%$ of the participants had $\geq 2$ sexual partners during their lifetime, and the prevalence of HPV infections was $8.6 \%$. At the 2-year follow-up, the prevalence of HPV infection decreased to $6.0 \%$. All participants and the high-risk group for HPV infection were most likely to live in Busan, have $\geq 2$ sexual partners during their lifetime, have a family history of cancer, and have a history of HPV infection at baseline (Table 1).

Among the $105 \mathrm{HPV}$ infections from the baseline, only 13 infections (12.4\%) were remained, and the 10 cases of them are HR-HPV types including genotype 33, 45, 16, 35, and 52 . Among the 1,119 women who tested negative at the baseline, 54 women (5\%) exhibited new HPV infections at the followup. The most frequent HPV genotypes found in new infection cases were genotypes 39, 52, 16, 51, and 58 (Table 2).

Persistent HPV infections were relatively common among unmarried women, women with $\geq 2$ more sexual partners during their lifetime, and women with a family history of cancer. Cleared and new infections were relatively common among women with a history of a sexually transmitted disease or Chlamydia infection. Persistent and new infections were more common in Busan, compared to Suwon (Table 3). 
Table 1. General characteristics of 1,224 study participants at the follow up by HPV infection status

\begin{tabular}{|c|c|c|c|c|c|}
\hline \multirow[t]{2}{*}{ Characteristic } & \multirow{2}{*}{$\begin{array}{c}\begin{array}{c}\text { Total } \\
(\mathrm{n}=1,224)\end{array} \\
\text { No. }(\%)\end{array}$} & \multicolumn{2}{|c|}{$\begin{array}{c}\text { Overall HPV } \\
\text { infection }{ }^{a}(n=73)\end{array}$} & \multicolumn{2}{|c|}{$\begin{array}{c}\text { HR HPV } \\
\text { infection }^{2)}(n=52)\end{array}$} \\
\hline & & No. $(\%)$ & p-value & No. $(\%)$ & p-value \\
\hline \multicolumn{6}{|l|}{ Region } \\
\hline Busan & $579(47.3)$ & $57(9.8)$ & 0.0001 & $41(7.1)$ & 0.001 \\
\hline Suwon & $645(52.7)$ & $16(2.5)$ & & $11(1.7)$ & \\
\hline \multicolumn{6}{|l|}{ Age group (yr) } \\
\hline$<39$ & $223(18.2)$ & $15(6.7)$ & 0.897 & $11(5.0)$ & 0.913 \\
\hline $40-49$ & $529(43.2)$ & $29(5.5)$ & & $23(4.3)$ & \\
\hline $50-59$ & $401(32.8)$ & $25(6.2)$ & & $16(4.0)$ & \\
\hline$\geq 60$ & $71(5.8)$ & $4(5.6)$ & & $2(2.8)$ & \\
\hline \multicolumn{6}{|l|}{ Marital status } \\
\hline Unmarried (single, divorced, and widower) & $204(16.7)$ & $16(7.8)$ & 0.214 & $10(4.9)$ & 0.612 \\
\hline Married (married and cohabitant) & $1,020(83.3)$ & $57(5.6)$ & & $42(4.1)$ & \\
\hline \multicolumn{6}{|l|}{ Education level } \\
\hline None/Elementary/Middle school & $496(40.5)$ & $34(6.8)$ & 0.277 & $24(4.8)$ & 0.398 \\
\hline High school/University / > Master & $728(59.5)$ & $39(5.4)$ & & $28(3.8)$ & \\
\hline \multicolumn{6}{|l|}{ First marriage age $(\mathrm{yr})$} \\
\hline$<25$ & $402(41.7)$ & $26(6.5)$ & 0.169 & $19(4.7)$ & 0.125 \\
\hline$\geq 25$ & $561(58.3)$ & $25(4.5)$ & & $16(2.8)$ & \\
\hline \multicolumn{6}{|l|}{ Smoking status } \\
\hline Non smoker & $1,150(94.0)$ & $70(6.0)$ & 1.000 & $49(4.2)$ & 0.474 \\
\hline Current smoker & $73(6.0)$ & $3(5.8)$ & & $3(5.8)$ & \\
\hline \multicolumn{6}{|l|}{ Alcohol drinking } \\
\hline No & $856(69.9)$ & $45(5.3)$ & 0.111 & $31(3.6)$ & 0.097 \\
\hline Yes & $368(30.1)$ & $28(7.6)$ & & $21(5.7)$ & \\
\hline \multicolumn{6}{|l|}{ Lifetime sexual partners } \\
\hline 1 & $1,003(82.2)$ & $49(4.9)$ & 0.001 & $34(3.4)$ & 0.003 \\
\hline$\geq 2$ & $217(17.8)$ & $23(10.6)$ & & $17(7.8)$ & \\
\hline \multicolumn{6}{|l|}{ Extramarital affair } \\
\hline No & $1,065(87.2)$ & $59(5.5)$ & 0.283 & $42(3.9)$ & 0.486 \\
\hline Yes & $156(12.8)$ & $12(7.7)$ & & $8(5.1)$ & \\
\hline \multicolumn{6}{|l|}{ Parity } \\
\hline 1 & $150(12.8)$ & $10(6.7)$ & 0.331 & $7(4.7)$ & 0.873 \\
\hline 2 & $719(61.5)$ & $38(5.3)$ & & $29(4.0)$ & \\
\hline$\geq 3$ & $300(25.7)$ & $23(7.7)$ & & $14(4.7)$ & \\
\hline \multicolumn{6}{|l|}{ Menopause } \\
\hline No & $506(41.4)$ & $35(6.9)$ & 0.24 & $22(4.3)$ & 0.889 \\
\hline Yes & $717(58.6)$ & $38(5.3)$ & & $30(4.2)$ & \\
\hline \multicolumn{6}{|l|}{ History of STDa) } \\
\hline No & $1,155(95.7)$ & $67(5.8)$ & 0.231 & $47(4.1)$ & 0.274 \\
\hline Yes & $52(4.3)$ & $5(9.6)$ & & $4(7.7)$ & \\
\hline \multicolumn{6}{|l|}{ Family history of cancer } \\
\hline No & $809(66.1)$ & $38(4.7)$ & 0.009 & $24(3.0)$ & 0.002 \\
\hline Yes & $414(33.9)$ & $35(8.4)$ & & $28(6.8)$ & \\
\hline \multicolumn{6}{|l|}{ Cervical screening history } \\
\hline No & $158(13.0)$ & $5(3.2)$ & 0.147 & $4(7.8)$ & 0.392 \\
\hline Yes & $1,058(87.0)$ & $67(6.3)$ & & $47(4.4)$ & \\
\hline \multicolumn{6}{|l|}{ Chlamydia trachomatis at baseline } \\
\hline Negative & $1,151(96.2)$ & $67(5.8)$ & 0.336 & $48(4.2)$ & 0.712 \\
\hline Positive & $45(3.8)$ & $4(8.9)$ & & $2(4.4)$ & \\
\hline
\end{tabular}

(Continued to the next page) 
Table 1. Continued

\begin{tabular}{|c|c|c|c|c|c|}
\hline \multirow[t]{2}{*}{ Characteristic } & \multirow{2}{*}{$\begin{array}{c}\begin{array}{c}\text { Total } \\
(n=1,224)\end{array} \\
\text { No. }(\%)\end{array}$} & \multicolumn{2}{|c|}{$\begin{array}{c}\text { Overall HPV } \\
\text { infection }^{\text {a) }}(n=73)\end{array}$} & \multicolumn{2}{|c|}{$\begin{array}{c}\text { HR HPV } \\
\text { infection }^{\text {a) }}(n=52)\end{array}$} \\
\hline & & No. $(\%)$ & $\overline{p \text {-value }}$ & No. $(\%)$ & p-value \\
\hline \multicolumn{6}{|c|}{ HPV status at baseline by LA } \\
\hline Negative & $1,119(91.4)$ & $54(4.8)$ & $<0.001$ & $36(3.2)$ & $<0.001$ \\
\hline Positive & $105(8.6)$ & $19(18.1)$ & & $16(15.2)$ & \\
\hline
\end{tabular}

$\mathrm{HPV}$, human papillomavirus; STD, sexual transmitted disease; LA, linear array. ${ }^{\text {a) }}$ Sample sizes for individual characteristics may not equal total due to missing values.

Table 2. HPV genotype distribution of 1,224 participants at the baseline and their changes at follow-up

\begin{tabular}{|c|c|c|c|c|c|}
\hline \multirow[b]{2}{*}{ HPV type } & \multirow[b]{2}{*}{ Total } & \multicolumn{3}{|c|}{ HPV positive at baseline $(n=105)$} & \multirow{2}{*}{$\begin{array}{c}\text { HPV negative at baseline }(\mathrm{n}=\mathbf{1 , 1 1 9 )} \\
\begin{array}{c}\text { Incidence at } \\
\left.\text { follow-up }^{\mathrm{a}}\right)\end{array}\end{array}$} \\
\hline & & $\begin{array}{l}\text { Persistence at } \\
\text { follow-upa) }\end{array}$ & $\begin{array}{l}\text { Clearance at } \\
\text { follow-up }\end{array}$ & $\begin{array}{l}\text { Reinfection at } \\
\text { follow-up }\end{array}$ & \\
\hline All $^{\text {a) }}$ & 105 & $13(12.4)$ & $92(87.6)$ & $12(11.4)$ & $54(4.8)$ \\
\hline High risk & 90 & $10(11.1)$ & $80(88.9)$ & $9(8.6)$ & $47(4.2)$ \\
\hline HPV 16 & 10 & $2(20.0)$ & $8(80.0)$ & 0 & $6(0.5)$ \\
\hline HPV 18 & 5 & 0 & $5(100)$ & 0 & $3(0.3)$ \\
\hline HPV 31 & 1 & 0 & $1(100)$ & 0 & $3(0.3)$ \\
\hline HPV 33 & 3 & $1(33.3)$ & $2(66.7)$ & 0 & 0 \\
\hline HPV 35 & 5 & $1(20.0)$ & $4(80.0)$ & 0 & 0 \\
\hline HPV 39 & 10 & $1(10.0)$ & $9(90.0)$ & $1(1.0)$ & $7(0.6)$ \\
\hline HPV 45 & 4 & $1(25.0)$ & $3(75.0)$ & $1(1.0)$ & $1(0.1)$ \\
\hline HPV 51 & 11 & 0 & 11 (100) & $1(1.0)$ & $6(0.5)$ \\
\hline HPV 52 & 15 & $3(20.0)$ & $12(80.0)$ & $4(3.8)$ & $7(0.6)$ \\
\hline HPV 56 & 12 & $1(8.3)$ & 11 (91.7) & $1(1.0)$ & $4(0.4)$ \\
\hline HPV 58 & 6 & 0 & $6(100)$ & 0 & $6(0.5)$ \\
\hline HPV 59 & 1 & 0 & $1(100)$ & 0 & $2(0.2)$ \\
\hline HPV 68 & 7 & 0 & 7 (100) & $1(1.0)$ & $2(0.2)$ \\
\hline Low risk & 90 & $7(7.8)$ & $83(92.2)$ & $8(7.6)$ & $48(4.3)$ \\
\hline HPV 6 & 3 & 0 & $3(100)$ & 0 & 0 \\
\hline HPV 40 & 2 & 0 & $2(100)$ & 0 & 0 \\
\hline HPV 42 & 1 & $1(100)$ & 0 & $1(1.0)$ & $2(0.2)$ \\
\hline HPV 54 & 5 & $1(20.0)$ & $4(80.0)$ & $1(1.0)$ & $3(0.3)$ \\
\hline HPV 53 & 15 & $1(6.7)$ & $14(94.3)$ & 0 & $8(0.7)$ \\
\hline HPV 55 & 6 & $1(16.7)$ & 5 (83.3) & $2(1.9)$ & $2(0.2)$ \\
\hline HPV 61 & 3 & $1(33.3)$ & $2(66.7)$ & $1(1.0)$ & $4(0.4)$ \\
\hline HPV 62 & 11 & $1(9.1)$ & $10(98.9)$ & $1(1.0)$ & $4(0.4)$ \\
\hline HPV 66 & 15 & 0 & 15 (100) & 0 & $1(0.1)$ \\
\hline HPV 70 & 10 & 0 & 10 (100) & $1(1.0)$ & $2(0.2)$ \\
\hline HPV 71 & 4 & 0 & $4(100)$ & $1(1.0)$ & $2(0.2)$ \\
\hline HPV 72 & 2 & 0 & $2(100)$ & 0 & $1(0.1)$ \\
\hline HPV 81 & 4 & 0 & $4(100)$ & 0 & $6(0.5)$ \\
\hline HPV 83 & 1 & 0 & $1(100)$ & 0 & $3(0.3)$ \\
\hline HPV 84 & 6 & $1(16.7)$ & $5(83.3)$ & 0 & $6(0.5)$ \\
\hline СР6108 & 2 & 0 & $2(100)$ & 0 & $2(0.2)$ \\
\hline
\end{tabular}

Values are presented as number (\%). ${ }^{\text {a) }}$ Same women can be counted more than once because of multiple infections. 
Table 3. Factors associated with type specific HPV persistence, clearance, and incidence ${ }^{a}$

\begin{tabular}{|c|c|c|c|c|}
\hline \multirow[t]{2}{*}{ Characteristic } & \multirow{2}{*}{$\begin{array}{c}\begin{array}{c}\text { Persistent HPV } \\
(\mathrm{n}=13)\end{array} \\
\text { No. }(\%)\end{array}$} & \multirow{2}{*}{$\begin{array}{c}\begin{array}{c}\text { Overall HPV } \\
(\mathrm{n}=92)\end{array} \\
\text { No. }(\%)\end{array}$} & \multicolumn{2}{|c|}{$\begin{array}{c}\text { Incident HPV } \\
(\mathrm{n}=54)\end{array}$} \\
\hline & & & No. $(\%)$ & $\overline{\text { p-value }}$ \\
\hline \multicolumn{5}{|l|}{ Region } \\
\hline Busan & $10(76.9)$ & $46(50.0)$ & $42(77.8)$ & $<0.001$ \\
\hline Suwon & $3(23.1)$ & $46(50.0)$ & $12(22.2)$ & \\
\hline \multicolumn{5}{|l|}{ Age group (yr) } \\
\hline$<39$ & $2(15.4)$ & $24(26.1)$ & $10(18.5)$ & 0.31 \\
\hline $40-49$ & $2(15.4)$ & $35(38.0)$ & $25(46.3)$ & \\
\hline $50-59$ & $8(61.5)$ & $27(29.4)$ & $16(29.6)$ & \\
\hline$\geq 60$ & $1(7.7)$ & $6(6.5)$ & $3(5.6)$ & \\
\hline \multicolumn{5}{|l|}{ Marital status } \\
\hline Unmarried & $6(46.2)$ & $19(20.6)$ & $8(14.8)$ & 0.036 \\
\hline Married & $7(53.9)$ & $73(79.4)$ & $46(85.2)$ & \\
\hline \multicolumn{5}{|l|}{ Educational level } \\
\hline None/Elementary / Middle school & $9(69.2)$ & $39(42.4)$ & $23(42.6)$ & 0.19 \\
\hline High school/University/ $\geq$ Master & $4(30.7)$ & $53(57.6)$ & $31(57.4)$ & \\
\hline \multicolumn{5}{|l|}{ Smoking status } \\
\hline Nonsmoker & $12(92.3)$ & $86(95.9)$ & $53(98.2)$ & 0.352 \\
\hline Smoker & $1(7.7)$ & $6(4.1)$ & $1(1.8)$ & \\
\hline \multicolumn{5}{|l|}{ Alcohol drinking } \\
\hline No & $8(61.5)$ & $58(63.1)$ & $34(62.9)$ & 0.201 \\
\hline Yes & $5(38.5)$ & $34(36.9)$ & $20(37.1)$ & \\
\hline \multicolumn{5}{|l|}{ Lifetime sexual partners } \\
\hline 1 & $8(61.5)$ & $64(70.3)$ & $38(71.7)$ & $<0.001$ \\
\hline$\geq 2$ & $5(38.5)$ & $27(29.7)$ & $15(28.3)$ & \\
\hline \multicolumn{5}{|l|}{ Parity } \\
\hline 1 & $2(16.6)$ & $9(11.1)$ & $6(11.3)$ & 0.393 \\
\hline 2 & $5(41.7)$ & $47(58.0)$ & $29(54.7)$ & \\
\hline$\geq 3$ & $5(41.7)$ & $25(30.9)$ & $18(34.0)$ & \\
\hline \multicolumn{5}{|l|}{ Hormone therapy use } \\
\hline Never user & $9(100)$ & $31(81.6)$ & $20(83.3)$ & 0.478 \\
\hline Ever user & 0 & 7 (18.4) & $4(16.7)$ & \\
\hline \multicolumn{5}{|l|}{ History of STD } \\
\hline No & $12(100)$ & $85(92.4)$ & $49(90.7)$ & 0.078 \\
\hline Yes & 0 & $7(7.6)$ & $5(9.3)$ & \\
\hline \multicolumn{5}{|l|}{ Family history of cancer } \\
\hline No & $5(38.5)$ & $57(62.0)$ & $29(53.7)$ & 0.021 \\
\hline Yes & $8(61.5)$ & $35(38.0)$ & $25(46.3)$ & \\
\hline \multicolumn{5}{|l|}{ Chlamydia trachomatis at baseline } \\
\hline Negative & $13(100)$ & $82(90.1)$ & $49(94.2)$ & 0.019 \\
\hline Positive & 0 & $9(9.9)$ & $3(5.8)$ & \\
\hline
\end{tabular}

HPV, human papillomavirus; STD, sexual transmitted disease. a)Sample sizes for individual characteristics may not equal total due to missing values.

After adjusting for all potential factors, having $\geq 2$ sexual partners exhibited a marginally significant association with new HPV infections (OR, 2.0; 95\% CI, 1.0 to 3.9). No factors were significantly associated with HPV persistence and clearance (Table 4). 
Table 4. ORs and 95\% CI of potential factors associated with HPV persistence, and incidence

\begin{tabular}{|c|c|c|c|c|c|c|}
\hline \multirow{3}{*}{ Characteristic } & \multicolumn{3}{|c|}{ HPV positive at baseline } & \multicolumn{3}{|c|}{ HPV negative at baseline } \\
\hline & \multirow{2}{*}{$\begin{array}{l}\text { Total HPV } \\
\quad(n=105)\end{array}$} & $\begin{array}{c}\text { Persistent HPV } \\
(\mathrm{n}=13)\end{array}$ & Adjusted OR & \multirow{2}{*}{$\begin{array}{c}\text { Total HPVa) } \\
(n=1,119)\end{array}$} & $\begin{array}{l}\text { Incident HPV } \\
\quad(n=54)\end{array}$ & Adjusted OR \\
\hline & & No. $(\%)$ & OR $(95 \% \mathrm{CI})$ & & No. $(\%)$ & OR $(95 \% \mathrm{CI})$ \\
\hline \multicolumn{7}{|l|}{ Age group (yr) } \\
\hline$<39$ & 26 & $2(7.7)$ & Ref & 197 & $10(5.1)$ & Ref \\
\hline $40-49$ & 37 & $2(5.4)$ & $1.0(0.1-8.8)$ & 492 & $25(5.1)$ & $1.2(0.5-3.9)$ \\
\hline $50-59$ & 35 & $8(22.7)$ & $4.6(0.7-29.0)$ & 366 & $16(4.4)$ & $1.0(0.4-2.4)$ \\
\hline$\geq 60$ & 7 & $1(14.3)$ & $3.4(0.3-60.1)$ & 64 & $3(4.7)$ & $1.1(0.3-4.2)$ \\
\hline \multicolumn{7}{|l|}{ Smoking status } \\
\hline Non-smoker & 98 & $12(12.2)$ & Ref & 1,074 & $53(4.9)$ & Ref \\
\hline Current smoker & 7 & $1(14.3)$ & $1.7(0.1-21.7)$ & 44 & $1(2.3)$ & $0.3(0.1-2.4)$ \\
\hline \multicolumn{7}{|c|}{ Lifetime sexual partners } \\
\hline 1 & 72 & $8(11.6)$ & Ref & 931 & $38(4.1)$ & Ref \\
\hline$\geq 2$ & 32 & $5(15.6)$ & $1.6(0.4-7.0)$ & 185 & $15(8.1)$ & $2.0(1.0-3.9)$ \\
\hline \multicolumn{7}{|c|}{ Family history of cancer } \\
\hline No & 62 & $5(8.1)$ & Ref & 747 & $29(3.9)$ & Ref \\
\hline Yes & 43 & $8(18.6)$ & $4.0(0.9-17.2)$ & 371 & $25(6.7)$ & $1.7(0.9-3.1)$ \\
\hline \multicolumn{7}{|l|}{ History of STD } \\
\hline No & 97 & $12(13.4)$ & Ref & 1,058 & $49(4.6)$ & Ref \\
\hline Yes & 7 & 0 & - & 45 & $5(11.1)$ & $2.3(0.8-6.2)$ \\
\hline \multicolumn{7}{|c|}{ Chlamydia trachomatis at baseline } \\
\hline Negative & 95 & $13(13.7)$ & Ref & 1,056 & $49(4.6)$ & Ref \\
\hline Positive & 9 & 0 & - & 36 & $3(8.3)$ & $1.3(0.3-5.5)$ \\
\hline
\end{tabular}

Adjustment was done using all variable presented in this table except region. OR, odds ratio; CI, confidence interval; $\mathrm{HPV}$,

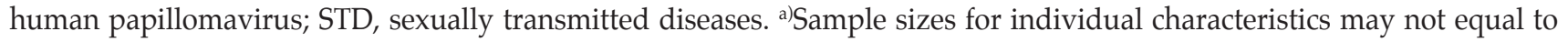
total due to missing values.

\section{Discussion}

The present study provided information regarding HPV genotype-specific infections and their change patterns among Korean women. These data are important, because relevant data are sparse in this population, despite the prevalence of HPV infection and incidence of cervical cancer. Furthermore, ours is the first report regarding the natural history of HPV infection among Korean women who visited clinics or hospitals for routine health examinations (e.g., cervical cancer screening), rather than for the diagnosis or treatment of gynecological symptoms. Moreover, we performed both HPV LA and HPV genotyping to confirm the HPV type-specific changes that occurred during the course of the patients' infections.

Most infections $(87.6 \%)$ were cleared within 2 years, although $5 \%$ of women developed new HPV infections during this time. These results are consistent with findings from previous reports, which suggested that up to $90 \%$ of incident infections are cleared within 2 years [5], and that the estimated half-life of HR-HPV infections is 8-10 months [6]. However, HPV persistency varies according to country, and our results revealed a lower persistency $(12.4 \%)$, compared to results from previous studies in Brazil (19.2\%) [9], Italy (49.1\%) [16], Denmark (31.4\% [21] and 26.9\% [12]), the United States (39\%) [10], and the Netherlands (44.1\%) [22]. These differences may be related to differences in the target populations, who may have different potential risks for persistent infection, and / or differences in the baseline and follow-up testing interval. Nevertheless, the result from a meta-analysis on the patterns of HPV persistence worldwide, the persistence rate tends to decrease with time passed after infection [23]. The association between age and HPV persistence remains controversial. A review of the natural history of HPV infection suggests that age indirectly affects HPV persistence [24], while others studies have reported that younger age is associated with an increased risk of persistence $[9,21]$. 
Our results were similar to the persistence rate among young Korean women (17-26 years), despite the differences in the study populations' ages and the higher rate of new HPV infections among young Korean women [8]. The present study also revealed that the most persistent HPV type was HPV 33, which was followed by genotypes $45,16,35$, and 52 . These results are different with the findings from previous studies, which revealed that HPV 16 and 18 were the most prevalent incident and persistent HPV types $[9,16,21,23]$.

After adjusting for potential risk factors, we did not observe any significant associations with HPV persistence. Some studies have revealed similar findings, although other studies have revealed significant positive $[11,12,16,25]$ or inverse $[9,21]$ associations between age and HPV persistence, including a large retrospective study of Korean women. Another study found that smokers were likely to have persistent HPV infections [22]. In the present study, the number of sexual partners was the only factor to exhibit a marginal association with new HPV infections, and this result is similar to the findings from previous studies [26-28]. The current findings including distributions of HPV genotype-specific infections and their change patterns among Korean women may help improve our understanding of the natural history of HPV infection in the same populations, and facilitate the development of prophylactic vaccines for specific populations.

The present study has several limitations that warrant consideration. First, there is the possibility of selection bias, based on the low follow-up participation rate. However, the participants exhibited similar characteristics at the baseline and follow-up testing, although HPV positivity was slightly more common at the follow-up (10.1\%), compared to the baseline $(7.7 \%$ ) (S1 Table). These differences are unlikely to have significantly influenced our findings. Second, the small samples of women who were followed-up and women with HPV ( $n=105$ ) might have influenced the absence of significant associations between HPV persistence and the potential risk factors in the multivariate analyses. Furthermore, the number of sexual partners not during the last two years when participants followed up but during their life time was included as one of important factors involving HPV infection status and their change. It could be linked to insignificant results on the association between sexual behaviors and change of HPV infection status. Nevertheless, our results regarding HPV change patterns evaluated a large number of Korean women at the baseline $(n=4,558)$, and lifetime sexual behavior could represent overall tendency of sexual behaviors even if it is not the specific sexual behaviors change during the time followed up. Third, detailed data regarding the natural history of HPV infection should be obtained using long-term studies with repeated measurements over shorter intervals (e.g., every 6 months or every year), and we only evaluated HPV infection status after a 2-year interval. Also, information on further diagnosis and treatment such as Pap smear, colposcopic biopsy, and laser therapy during the follow up periods, which might be important factors associated with change of HPV infection status, were not available in this study. Fourth, HPV genotyping was only performed for HPV LA-positive cases at the baseline, although there was disagreement between the test results from HPV LA (6.0\%) and HPV HC2 (7.0\%) (data not shown). However, the correlation of HPV LA with HR HPV positivity is higher than that with HPV HC2, and this level of disagreement is likely acceptable, based on previously reported results $[29,30]$.

In conclusion, the present study provided information regarding changes in HPV status over a 2-year interval among Korean women. Most infections resolved spontaneously, and only small fractions of the women experienced persistent infections or new HPV infections. The predominant persistent HPV genotypes were different in our study, compared to those from previous studies. We also found a marginally significant association between sexual behavior and HPV infection, but not with HPV persistence or clearance. Further large-scale studies are needed to better understand the natural history of HPV infections and the factors that are associated with HPV type-specific change patterns.

\section{Electronic Supplementary Material}

Supplementary materials are available at Cancer Research and Treatment website (http:// www.e-crt.org).

\section{Conflicts of Interest}

Conflict of interest relevant to this article was not reported.

\section{Acknowledgments}

This study was supported by research grants from the National Cancer Center (No. 0410130, 0710140, 1610200), Republic of Korea. 


\section{References}

1. Clifford G, Franceschi S, Diaz M, Munoz N, Villa LL. Chapter 3: HPV type-distribution in women with and without cervical neoplastic diseases. Vaccine. 2006;24 Suppl 3:S3/26-34.

2. Peto J, Gilham C, Deacon J, Taylor C, Evans C, Binns W, et al. Cervical HPV infection and neoplasia in a large populationbased prospective study: the Manchester cohort. Br J Cancer. 2004;91:942-53.

3. Munoz N, Castellsague X, de Gonzalez AB, Gissmann L. Chapter 1: HPV in the etiology of human cancer. Vaccine. 2006;24 Suppl 3:S3/1-10.

4. Kim J, Kim BK, Lee CH, Seo SS, Park SY, Roh JW. Human papillomavirus genotypes and cofactors causing cervical intraepithelial neoplasia and cervical cancer in Korean women. Int J Gynecol Cancer. 2012;22:1570-6.

5. Bosch FX, Burchell AN, Schiffman M, Giuliano AR, de Sanjose S, Bruni L, et al. Epidemiology and natural history of human papillomavirus infections and type-specific implications in cervical neoplasia. Vaccine. 2008;26 Suppl 10:K1-16.

6. Castellsague X. Natural history and epidemiology of HPV infection and cervical cancer. Gynecol Oncol. 2008;110 (3 Suppl 2):S4-7.

7. Syrjanen S, Shabalova I, Petrovichev N, Podistov J, Ivanchenko O, Zakharenko S, et al. Age-specific incidence and clearance of high-risk human papillomavirus infections in women in the former Soviet Union. Int J STD AIDS. 2005;16: 217-23.

8. Oh JK, Ju YH, Franceschi S, Quint W, Shin HR. Acquisition of new infection and clearance of type-specific human papillomavirus infections in female students in Busan, South Korea: a follow-up study. BMC Infect Dis. 2008;8:13.

9. Rosa MI, Fachel JM, Rosa DD, Medeiros LR, Igansi CN, Bozzetti MC. Persistence and clearance of human papillomavirus infection: a prospective cohort study. Am J Obstet Gynecol. 2008;199:617.e1-7.

10. Ralston Howe E, Li Z, McGlennen RC, Hellerstedt WL, Downs LS Jr. Type-specific prevalence and persistence of human papillomavirus in women in the United States who are referred for typing as a component of cervical cancer screening. Am J Obstet Gynecol. 2009;200:245.e1-7.

11. Louvanto K, Rintala MA, Syrjanen KJ, Grenman SE, Syrjanen SM. Genotype-specific persistence of genital human papillomavirus (HPV) infections in women followed for 6 years in the Finnish Family HPV Study. J Infect Dis. 2010;202:436-44.

12. Nielsen A, Kjaer SK, Munk C, Osler M, Iftner T. Persistence of high-risk human papillomavirus infection in a populationbased cohort of Danish women. J Med Virol. 2010;82:616-23.

13. Ye J, Cheng X, Chen X, Ye F, Lu W, Xie X. Short-term typespecific HPV persistence and its predictors in an asymptomatic general female population in Zhejiang, China. Int J Gynaecol Obstet. 2010;110:217-22.

14. Marks M, Gravitt PE, Gupta SB, Liaw KL, Tadesse A, Kim E, et al. Combined oral contraceptive use increases HPV persistence but not new HPV detection in a cohort of women from Thailand. J Infect Dis. 2011;204:1505-13.
15. Miranda PM, Silva NN, Pitol BC, Silva ID, Lima-Filho JL, Carvalho RF, et al. Persistence or clearance of human papillomavirus infections in women in Ouro Preto, Brazil. Biomed Res Int. 2013;2013:578276.

16. Sammarco ML, Del Riccio I, Tamburro M, Grasso GM, Ripabelli G. Type-specific persistence and associated risk factors of human papillomavirus infections in women living in central Italy. Eur J Obstet Gynecol Reprod Biol. 2013;168:222-6.

17. Schmeink CE, Massuger LF, Lenselink CH, Quint WG, Witte BI, Berkhof J, et al. Prospective follow-up of 2,065 young unscreened women to study human papillomavirus incidence and clearance. Int J Cancer. 2013;133:172-81.

18. Bae JH, Lee SJ, Kim CJ, Hur SY, Park YG, Lee WC, et al. Human papillomavirus (HPV) type distribution in Korean women: a meta-analysis. J Microbiol Biotechnol. 2008;18: 788-94.

19. Jung KW, Won YJ, Kong HJ, Oh CM, Cho H, Lee DH, et al. Cancer statistics in Korea: incidence, mortality, survival, and prevalence in 2012. Cancer Res Treat. 2015;47:127-41.

20. Oh JK, Franceschi S, Kim BK, Kim JY, Ju YH, Hong EK, et al. Prevalence of human papillomavirus and Chlamydia trachomatis infection among women attending cervical cancer screening in the Republic of Korea. Eur J Cancer Prev. 2009;18: 56-61.

21. Stensen S, Kjaer SK, Jensen SM, Frederiksen K, Junge J, Iftner $\mathrm{T}$, et al. Factors associated with type-specific persistence of high-risk human papillomavirus infection: a population-based study. Int J Cancer. 2016;138:361-8.

22. Schmeink CE, Melchers WJ, Siebers AG, Quint WG, Massuger LF, Bekkers RL. Human papillomavirus persistence in young unscreened women, a prospective cohort study. PLoS One. 2011;6:e27937.

23. Mollers M, Boot Hein J, Vriend Henrike J, King Audrey J, van den Broek Ingrid VF, van Bergen Jan EA, et al. Prevalence, incidence and persistence of genital HPV infections in a large cohort of sexually active young women in the Netherlands. Vaccine. 2013;31:394-401.

24. Moscicki AB, Schiffman M, Burchell A, Albero G, Giuliano AR, Goodman MT, et al. Updating the natural history of human papillomavirus and anogenital cancers. Vaccine. 2012;30 Suppl 5:F24-33.

25. Syrjanen S, Shabalova I, Petrovichev N, Kozachenko V, Zakharova T, Pajanidi J, et al. Factors predicting persistence of high-risk human papillomavirus (HPV) infections in women prospectively followed-up in three New Independent States (NIS) of the former Soviet Union. Eur J Gynaecol Oncol. 2005;26:491-8.

26. Castellsague X, Bosch FX, Munoz N, Meijer CJ, Shah KV, de Sanjose $S$, et al. Male circumcision, penile human papillomavirus infection, and cervical cancer in female partners. $\mathrm{N}$ Engl J Med. 2002;346:1105-12.

27. International Collaboration of Epidemiological Studies of Cervical Cancer. Cervical carcinoma and sexual behavior: collaborative reanalysis of individual data on 15,461 women with 
cervical carcinoma and 29,164 women without cervical carcinoma from 21 epidemiological studies. Cancer Epidemiol Biomarkers Prev. 2009;18:1060-9.

28. Moscicki AB, Schiffman M, Kjaer S, Villa LL. Chapter 5: Updating the natural history of HPV and anogenital cancer. Vaccine. 2006;24 Suppl 3:S3 /42-51.

29. Gravitt PE, Schiffman M, Solomon D, Wheeler CM, Castle PE. A comparison of linear array and hybrid capture 2 for detec- tion of carcinogenic human papillomavirus and cervical precancer in ASCUS-LSIL triage study. Cancer Epidemiol Biomarkers Prev. 2008;17:1248-54.

30. Cook DA, Mei W, Smith LW, van Niekerk DJ, Ceballos K, Franco EL, et al. Comparison of the Roche cobas(R) 4800 and Digene Hybrid Capture(R) $2 \mathrm{HPV}$ tests for primary cervical cancer screening in the HPV FOCAL trial. BMC Cancer. 2015;15:968. 